\title{
Implementation of Mathematical Equation for Calculating Alumina Extraction from Bauxite Tailing Digestion
}

\author{
Saini $\mathrm{Hu}$ \\ Mineral and Coal Technology Research and Development CenterJalan Jenderal Sudirman No. 623 Bandung-Indonesia
}

\begin{abstract}
Research on bauxite digesting using pressurized reactor at a capacity of $86,66 \mathrm{~kg}$ of feed/batch had been conducted. Bauxite with $\mathbf{- 1 5 0}$ mesh of particle size is reacted with $42,15 \mathrm{~kg}$ of caustic soda with concentration of $433,49 \mathrm{~g} / \mathrm{l}$ at the temperature of $140^{\circ} \mathrm{C}$ for 1.0 to 2.5 hours using steam as heating media. Lime added are varied from 3 to $9 \mathrm{~kg}$. After processing for a certain period of time, slurry product is transferred into a Mixer. To evaluate percent yield of $\mathrm{Al}_{2} \mathrm{O}_{3}$ extraction from this process, measuring the height of slurry level in the Mixer, densities of the slurry, filtrate, and solid residue are conducted. Head sample of bauxite, filtrate and residue are analysed by using wet method to get $\mathrm{Al}_{2} \mathrm{O}_{3}$ content of each sample taken from the Mixer. There are four equations that are used for obtaining percent yield of $\mathrm{Al}_{2} \mathrm{O}_{3}$ extraction, namely:1) $\left.\left.\mathrm{V}_{\mathrm{sl}}=4.176 \mathrm{x}+15.83 ; 2\right) \mathrm{W}_{\mathrm{sl}}=(4.176 \mathrm{x}+15.83) * \rho_{\mathrm{s}} ; 3\right) \mathrm{S}=\left(\rho_{\mathrm{sl}}{ }^{-}\right.$ $\left.\rho_{\mathrm{l}}\right) /\left(\rho_{\mathrm{s}}-\rho_{\mathrm{l}}\right)\left(\rho_{\mathrm{s}} / \rho_{\mathrm{sl}}\right) * 100 \%$ and 4$) \mathrm{E}=\left[10(4.176 \mathrm{x}+15.83)\left[1-\left(\rho_{\mathrm{sl}}-\rho_{\mathrm{l}}\right) /\right.\right.$ $\left.\left(\rho_{s}-\rho_{1}\right)\right]^{*}\left[c_{1} / F_{x_{F}}\right] \%$. Where: $V_{s l}$ is volume of slurry in the Mixer (litre); $x$ is height of slurry level in the Mixer $(\mathrm{cm}) ; W_{\text {sl }}$ is weight of slurry in the Mixer (kg); $\mathrm{S}$ is solid percentage of slurry $(\%)$; $\rho_{\mathrm{sl}}$ is density of slurry $(\mathrm{kg} / \mathrm{l}) ; \rho_{\mathrm{s}}$ is density of residue $(\mathrm{kg} / \mathrm{l}) ; \rho_{\mathrm{l}}$ is density of filtrate $(\mathrm{kg} / \mathrm{l}) ; \mathrm{C}_{1}$ is concentration of $\mathrm{Al}_{2} \mathrm{O}_{3}$ in filtrate $(\mathrm{g} / \mathrm{l}) ; \mathrm{E}$ is percent yield of $\mathrm{Al}_{2} \mathrm{O}_{3}$ extraction (\%). By using those four equations, it can be obtained the results of the research as follows: by the increase of lime added into slurry, percent yield of $\mathrm{Al}_{2} \mathrm{O}_{3}$ extraction tend to decrease from $46.63 \%$ for $3 \mathrm{~kg}$ of lime to $15,84 \%$ by using $9 \mathrm{~kg}$ of lime. Whereas by varying reaction time between 1.0-2.5 hours, percent yield of $\mathrm{Al}_{2} \mathrm{O}_{3}$ extraction are fluctuation in the range of $42,07-60,54 \%$ with 1.5 hours of reaction time is the highest result. By implementing those four equations above for evaluating the data, we do not need to weigh the slurry in the Mixer.
\end{abstract}

Keywords-bauxite tailing; digesting; percent yield; alumina extraction; mathematical model; Bayer process

\section{INTRODUCTION}

\section{A Background}

Bauxite is heterogeneous material principally composed of aluminum oxide minerals and some impurities minerals. It is usually comprised of gibbsite, aluminogoethite, hematite, kaolin, quartz, and minor boehmite [1] and is being used in chemical, cement, refractory, abrasive, fertilizer, steel and other industries [2]. There are some bauxite companies which have been operating in Indonesia such as PT Aneka Tambang and PT Harita. Those companies usually use open pit method to mine crude bauxite from its deposit in the earth. They use backhoe to dig crude bauxite and product's mine is then transferred by dump truck to washing plant area.
Washing is one of methods that are usually used to upgrade alumina content of bauxite by separating primary mineral impurities like clay, silica, iron, and titanium that are attached on the surface of crude bauxite [3]. Trommol screen is common equipment to wash and screen coarse bauxite from very fine particles size by supporting pressurized spray water. By using water spraying and screening, smaller particles attached on the surface of crude bauxite is easy to separate. Therefore, there are two products of washing, namely washed bauxite having $+2 \mathrm{~mm}$ of particle size with high content of alumina and tailing having $-2 \mathrm{~mm}$ of particle size with lower content of alumina. The amount of tailing resulting from crude bauxite washing is a lot, it is about $50 \%$ by weight of crude bauxite that is being washed. PT Antam is now producing washed bauxite about 750,000 ton per year to supply PT Indonesia Chemical Alumina that has being produced chemical grade alumina with a capacity is around 300,000 ton alumina per year using Bayer's method. So, the amount of crude bauxite to be mined by PT Antam is around $1,500,000$ ton per year that generates washing tailing about 750.000 ton per year. Up to now, this bauxite tailing is thrown away into tailing pond and has not been utilized yet. So, it will endanger the environment if it is not handled properly. Besides, it needs very big space for preparing pond to collect tailing from bauxite washing, so it will be costly. In the effort to minimize the problem, Mineral and Coal Technology Research and Development Center has been trying to process tailing to become sodium aluminates solution that can be utilized as a raw material for polyaluminum chloride, alum, or synthetic zeolite production.

\section{B Bayer's Process}

Bayer's process is the only one technology applied all over the world for producing alumina economically. There are four steps of processing to produce alumina from bauxite, namely digesting, filtering, precipitation, and calcination [4, 5]. Fine bauxite ( -150 mesh of particle size) is digested in pressurized reactor (Autoclave) at a certain temperature and pressure, depending on type of bauxite which will be processed. Usually, the digesting temperature in the range of 140-160oC for gibbsite type of bauxite and 220-280oC for bochmite type of bauxite [6]. Chemical reaction occured for bauxite digestion is as follows :

$\mathrm{Al}_{2} \mathrm{O}_{3} \cdot 3 \mathrm{H}_{2} \mathrm{O}+2 \mathrm{NaOH}_{\mathrm{aq}} \rightarrow \mathrm{Na}_{2} \mathrm{O} \cdot \mathrm{Al}_{2} \mathrm{O}_{3}+4 \mathrm{H}_{2} \mathrm{O}$ (sodium aluminate) 
In addition to dissolve alumina content, caustic soda will also react with reactive silica contained in the bauxite tailing as described in chemical reaction bellows [3]:

$2 \mathrm{NaOH}+\mathrm{SiO}_{2} \rightarrow \mathrm{Na}_{2} \mathrm{O} \cdot \mathrm{SiO}_{2}+\mathrm{H}_{2} \mathrm{O}$ (sodium silicate)

Then sodium aluminate will react with sodium silicate providing chemical reaction as follows:

$\mathrm{Na}_{2} \mathrm{O} \cdot \mathrm{Al}_{2} \mathrm{O}_{3}+2\left(\mathrm{Na}_{2} \mathrm{O} \cdot \mathrm{SiO}_{2}\right)+4 \mathrm{H}_{2} \mathrm{O}=\mathrm{Na}_{2} \mathrm{O} \cdot \mathrm{Al}_{2} \mathrm{O}_{3} \cdot 2 \mathrm{SiO}_{2}$ $+2 \mathrm{H}_{2} \mathrm{O}+4 \mathrm{NaOH}$ (sodalite)

Sodalite will combine with red mud to be wastes that should be managed properly.

In this research, bauxite tailing to be processed belongs to gibbsite type of bauxite, therefore the temperature of digesting that has been used around $140^{\circ} \mathrm{C}$ is suitable for this process. Product of digesting is slurry form containing sodium aluminate and red mud. By filterring using filter press, clear sodium aluminate solution is produced separated from red mud cake. To convert sodium aluminate into alumina trihydrate $\left[\mathrm{Al}(\mathrm{OH})_{3}\right]$ precipitate, for conventional method, seed of fine $\mathrm{Al}(\mathrm{OH})_{3}$ is added into sodium aluminate solution during hydrolisys process that can achieve precipitation ratio of $55 \%$. Hydrolysis is conducted at a certain temperature; boehmite can be precipitated at the temperature above $90^{\circ} \mathrm{C}$ for isothermal condition and between $70-90^{\circ} \mathrm{C}$ for non isothermal condition. The yield of boehmite precipitation is in between $35-40 \%$ [5]. The alumina concentration in the supersaturated sodium aluminate solution is in between $80-200 \mathrm{~g} / \mathrm{l}$ with best value $132 \mathrm{~g} \mathrm{Al}_{2} \mathrm{O}_{3} / 1$. Caustic soda concentration in the supersaturated sodium aluminate solution is varying between $50-250 \mathrm{~g} / 1$ with best value $120 \mathrm{~g} / 1$ [5]. By adding methanol, a proper temperature for sodium aluminate hydrolysis is about $64.5{ }^{\circ} \mathrm{C}$ with maximum equilibrium precipitation ratios is about $83 \%$ after 24 hours and stated that the lower viscosity at higher temperature is a factor that enhances the yield and makes the effect of temperature is small [7].

The washed product of $\mathrm{Al}(\mathrm{OH})_{3}$ is then dried and calcined at hight temperature in the range of $1010-1260^{\circ} \mathrm{C}$ in a rotary kiln or fluidized bed calciners to drive off the molecules of hydrated water to become alumina: $\mathrm{Al}_{2} \mathrm{O}_{3} 3 \mathrm{H}_{2} \mathrm{O}$ $=\mathrm{Al}_{2} \mathrm{O}_{3}+3 \mathrm{H}_{2} \mathrm{O}$ or $2 \mathrm{Al}(\mathrm{OH})_{3}=2 \mathrm{Al}_{2} \mathrm{O}_{3}+3 \mathrm{H}_{2} \mathrm{O}[4,5,8]$. To improve Bayer's process performance, lime or its derivatives can be used to reduce caustic soda consumption, especially at higher temperatures. Lime increases the desilication efficiency of the bauxite digesting. In addition to reduce silica content in sodium aluminate solution, lime can also minimize impurities like carbonate, silica, and phosphor of this solution [1]. Sodium aluminate solution is most widely used in municipal drinking water and waste water treatment systems as coagulating agent to improve flocculation, and for removing dissolved silica and phosphates. It is also used in the paper industry, for fire brick production, alumina production and synthetic zeolites. In construction technology, sodium aluminate is employed to accelerate the solidification of concrete, mainly when working during frost [9]. In this paper, research activities just only focused on the first and the second steps, namely digesting and filtering.

\section{Mathematical Model for Data Evaluation}

To make it easy and practices in carrying out research activities on bauxite tailing digesting, especially in evaluating the data obtained from the research, a mathematical model is used to determine some parameter such as slurry volume, slurry weight, solid percentage, and percent yield of alumina extraction. This paper will discuss the result of the research on digesting of bauxite tailing washing originated from Meliau, West Kalimantan, Indonesia.

\section{1)To determine volume at any height level of Mixer}

To determine Mixer volume at any height of water level, callibration method has been conducted. First, empty a Mixer and acquire zero point in the system. Second, a certain volume of water is put in Mixer and write down the height of water level in Mixer. Third, repeat it this way until relation between water volume (V) and height of water level (x) a long the height of Mixer are collected and then make a graph to get an equation. The equation obtained is $\mathrm{V}=4.176 \mathrm{x}+15.83$ (Figure II).

\section{2)To determine slurry volume in Mixer}

The height of slurry level (x) in Mixer obtained during experiment is shown in Table I. By using equation : $\mathrm{Vsl}=4.176 \mathrm{x}+15.83$, the slurry volume at any digesting condition can be determined.

\section{3)To determine slurry weight in Mixer}

Slurry weight at a certain volume in Mixer can be calculated by multiplying slurry volume $\left(\mathrm{V}_{\mathrm{sl}}\right)$ with slurry density $\left(\rho_{\mathrm{sl}}\right)$. So, the formula can be written down as follows:

$$
\mathrm{W}_{\mathrm{sl}}=\mathrm{V}_{\mathrm{sl}} \rho_{\mathrm{sl}} \text {. Therefore }: \mathrm{W}_{\mathrm{sl}}=(4.176 \mathrm{x}+15.83)^{*} \rho_{\mathrm{sl}}
$$

\section{4)To determine solid weight in Mixer}

Solid weight can be calculated as follows: filtrate volume is slurry volume minus solid volume

$$
\begin{aligned}
& \mathrm{V}_{\mathrm{l}}=\mathrm{V}_{\mathrm{sl}}-\mathrm{V}_{\mathrm{s}} \\
& \mathrm{W}_{\mathrm{s}}=\mathrm{W}_{\mathrm{sl}}-\mathrm{W}_{\mathrm{l}} \\
& \mathrm{W}_{\mathrm{s}}=\mathrm{V}_{\mathrm{s}} \rho_{\mathrm{s}} \text { and } \mathrm{W}_{\mathrm{sl}}=\mathrm{V}_{\mathrm{sl}} \rho_{\mathrm{sl}} \text { and } \mathrm{W}_{\mathrm{l}}=\mathrm{V}_{\mathrm{l}} \rho_{\mathrm{l}} \\
& \left.\mathrm{V}_{\mathrm{s} \cdot} \rho_{\mathrm{s}}=\left(\mathrm{V}_{\mathrm{sl}} \rho_{\mathrm{sl}}-\mathrm{V}_{\mathrm{l}} \rho_{\mathrm{l}}\right) \rightarrow \mathrm{V}_{\mathrm{s}} \cdot \rho_{\mathrm{s}}=\left[\mathrm{V}_{\mathrm{sl}} \rho_{\mathrm{sl}}-\left(\mathrm{V}_{\mathrm{sl}}-\mathrm{V}_{\mathrm{s}}\right) \cdot \rho_{\mathrm{l}}\right)\right] \\
& \mathrm{V}_{\mathrm{s} \cdot} \rho_{\mathrm{s}}=\left(\mathrm{V}_{\mathrm{sl}} \rho_{\mathrm{sl}}-\mathrm{V}_{\mathrm{sl}} \rho_{\mathrm{l}}+\mathrm{V}_{\mathrm{s}} \rho_{\mathrm{l}}\right) \\
& \mathrm{V}_{\mathrm{s}}\left(\rho_{\mathrm{s}}-\rho_{\mathrm{l}}\right)=\mathrm{V}_{\mathrm{sl}}\left(\rho_{\mathrm{sl}}-\rho_{\mathrm{l}}\right) \\
& \mathrm{V}_{\mathrm{s}}=\mathrm{V}_{\mathrm{sl}}\left(\rho_{\mathrm{sl}}-\rho_{\mathrm{l}}\right) /\left(\rho_{\mathrm{s}}-\rho_{\mathrm{l}}\right) \\
& \mathrm{W}_{\mathrm{s}}=\mathrm{V}_{\mathrm{sl}}\left(\rho_{\mathrm{sl}}-\rho_{\mathrm{l}}\right) /\left(\rho_{\mathrm{s}}-\rho_{\mathrm{l}}\right) \rho_{\mathrm{s}} \\
& \mathrm{W}_{\mathrm{s}}=\left(\rho_{\mathrm{sl}}-\rho_{\mathrm{l}}\right) /\left(\rho_{\mathrm{s}}-\rho_{\mathrm{l}}\right) \rho_{\mathrm{s}}(4.176 \mathrm{x}+15.83)
\end{aligned}
$$

5) To determine solid percentage in Mixer $[10,11]$ $100 \%$

$$
\mathrm{W}_{\mathrm{sl}}=\mathrm{V}_{\mathrm{sl}} \rho_{\mathrm{sl}}
$$

Solid percentage $(\%)=($ Solid weight/Slury weight $) \mathrm{x}$

$$
\begin{aligned}
& \mathrm{S}=\mathrm{W}_{\mathrm{s}} / \mathrm{W}_{\mathrm{sl}} \times 100(\%) \\
& \mathrm{S}=\mathrm{V}_{\mathrm{sl}}\left(\rho_{\mathrm{sl}}-\rho_{\mathrm{l}}\right) /\left(\rho_{\mathrm{s}}-\rho_{\mathrm{l}}\right) \rho_{\mathrm{s}} / \mathrm{V}_{\mathrm{sl}} \rho_{\mathrm{sl}} \times 100(\%)
\end{aligned}
$$




$$
\mathrm{S}=\left(\rho_{\mathrm{sl}}-\rho_{\mathrm{l}}\right) /\left(\rho_{\mathrm{s}}-\rho_{\mathrm{l}}\right)\left(\rho_{\mathrm{s}} / \rho_{\mathrm{sl}}\right) \times 100(\%)
$$

6)To determine percent extraction [12, 13]

From the above equation, liquid volume can be calculated as follows:

$$
\begin{aligned}
& \mathrm{V}_{\mathrm{l}}=\mathrm{V}_{\mathrm{sl}}-\mathrm{V}_{\mathrm{s}} \\
& \mathrm{V}_{\mathrm{s}}=\mathrm{V}_{\mathrm{sl}}\left(\rho_{\mathrm{sl}}-\rho_{\mathrm{l}}\right) /\left(\rho_{\mathrm{s}}-\rho_{\mathrm{l}}\right) \\
& \mathrm{V}_{\mathrm{l}}=\mathrm{V}_{\mathrm{sl}}-\mathrm{V}_{\mathrm{sl}}\left(\rho_{\mathrm{sl}}-\rho_{\mathrm{l}}\right) /\left(\rho_{\mathrm{s}}-\rho_{\mathrm{l}}\right)=\mathrm{V}_{\mathrm{sl}}\left[1-\left(\rho_{\mathrm{sl}}-\rho_{\mathrm{l}}\right) /\left(\rho_{\mathrm{s}}-\rho_{\mathrm{l}}\right)\right]
\end{aligned}
$$

The equation should be used to calculate percent yield of $\mathrm{Al}_{2} \mathrm{O}_{3}$ extraction is as follows: $\mathrm{E}$ is alumina weight in filtrate is divided by alumina weight in feed times $100 \%$. $\mathrm{E}=\left(\mathrm{V}_{\mathrm{l}} \mathrm{c}_{\mathrm{l}} / 1000\right) /\left(\mathrm{Fx}_{\mathrm{F}} / 100\right) \times 100 \%=10 \mathrm{~V}_{1} \mathrm{c}_{\mathrm{l}} / \mathrm{Fx}_{\mathrm{F}}(\%)$ $\mathrm{E}=10 \mathrm{~V}_{1} \mathrm{c}_{\mathrm{l}} / \mathrm{Fx}_{\mathrm{F}}(\%)=\left[10 \mathrm{~V}_{\mathrm{sl}}\left[1-\left(\rho_{\mathrm{sl}}-\rho_{\mathrm{l}}\right) /\left(\rho_{\mathrm{s}}-\rho_{\mathrm{l}}\right)\right] *\left[\mathrm{c}_{\mathrm{l}} / \mathrm{Fx}_{\mathrm{F}}\right](\%)\right.$ $\mathrm{E}=\left[10(4.176 \mathrm{x}+15.83)\left[1-\left(\rho_{\mathrm{sl}}-\rho_{\mathrm{l}}\right) /\left(\rho_{\mathrm{s}}-\rho_{\mathrm{l}}\right)\right] *\left[\mathrm{c}_{\mathrm{l}} / \mathrm{FX}_{\mathrm{F}}\right](\%)\right.$

Where :

$\mathrm{V}_{1}=$ volume of filtrate in Mixer $(\mathrm{L})$;

$\mathrm{c}_{\mathrm{l}}=$ concentration of $\mathrm{Al}_{2} \mathrm{O}_{3}$ in filtrate $(\mathrm{g} / \mathrm{L})$;

$\mathrm{F}=$ feed weight $(\mathrm{kg}) ; \mathrm{x}_{\mathrm{F}}=\mathrm{Al}_{2} \mathrm{O}_{3}$ grade in feed (\%);

$\mathrm{V}_{\mathrm{sl}}$ is volume of slurry in the Mixer (litre);

$\mathrm{x}$ is height of slurry level in the Mixer $(\mathrm{cm})$;

$\mathrm{W}_{\mathrm{sl}}$ is weight of slurry in the Mixer $(\mathrm{kg})$;

$\mathrm{S}$ is solid percentage of slurry $(\%)$;

$\rho_{\mathrm{sl}}$ is density of slurry $(\mathrm{kg} / \mathrm{l})$;

$\rho_{\mathrm{s}}$ is density of residue $(\mathrm{kg} / \mathrm{l})$;

$\rho_{\mathrm{l}}$ is density of filtrate $(\mathrm{kg} / \mathrm{l})$;

$\mathrm{C}_{1}$ is concentration of $\mathrm{Al}_{2} \mathrm{O}_{3}$ in filtrate $(\mathrm{g} / \mathrm{l})$;

$\mathrm{E}$ is extraction of $\mathrm{Al}_{2} \mathrm{O}_{3}(\%)$.

\section{MethodOLOGY}

Bauxite tailing used for the experiment is from Tayan, West Kalimantan, Indonesia having -150 mesh of particle size and average $\mathrm{Al}_{2} \mathrm{O}_{3}$ content of $27,89 \%$. Other raw materials used are caustic soda, lime and water. The mixture consisting of $86.66 \mathrm{~kg}$ bauxite tailing, $42.15 \mathrm{~kg} \mathrm{NaOH}, 87.5$ $\mathrm{kg}$ water and lime at certain weight are put into an Autoclave. The mixture in the Autoclave is then heated and contacted directly with steam generated from boiler. The steam having pressure about 4 atmosphere and temperature around $140^{\circ} \mathrm{C}$ is used for heating media. Variables observed include lime doses and reaction time. Lime doses vary from 3 to $9 \mathrm{~kg}$ for $86.66 \mathrm{~kg}$ of feed and reaction time varies from 1 to 2.5 hours. After digesting process is finished, slurry product from Autoclave is flown into the sump and then diluted with water before pumping into Mixer. Slurry level in the Mixer is then measured to calculate slurry volume in the Mixer. After that, the slurry in the Mixer is sampled and divided into two parts, one sample for filtering to get filtrate and red mud, another sample for physical analysis. Densities and $\mathrm{Al}_{2} \mathrm{O}_{3}$ contents of all those samples including slurry, filtrate, and red mud are then analysed. Using all data obtained, percent yield of alumina extraction can be calculated. There are four steps to obtain percent yield of alumina extraction, namely a) determination of slurry volume; b) determination of slurry weight; c) determination of solid percentage of the slurry; and d) calculation of percent yield of alumina extraction. Flow diagram of the experiment is shown in Figure I. First, bauxite tailing is ground to -150 mesh using ball mill, followed by digestion it by using caustic soda in an Autoclave, after that transferring slurry of digestion product from Autoclave into Mixer, finally filterring slurry by using filter press to get clear sodium aluminate solution separated from red mud.

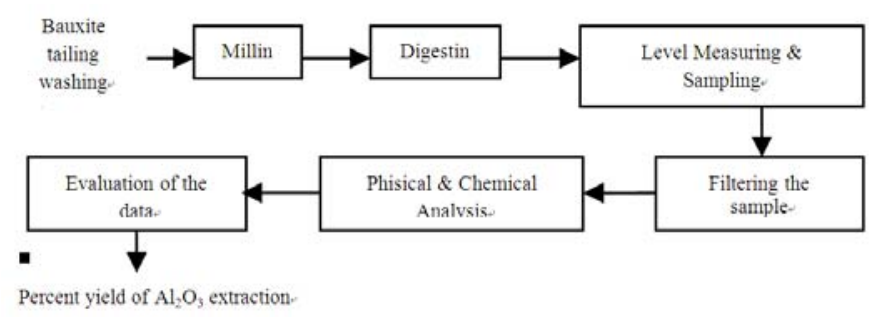

FIGURE I. FLOW SHEET FOR BAUXITE TAILING DIGESTING AND METHOD FOR EXPERIMENTAL DATA RESULT EVALUATION

\section{RESULT AND DISCUSSION}

To determine percent yield of $\mathrm{Al}_{2} \mathrm{O}_{3}$ extraction from bauxite tailing digesting, some data should be collected, those are slurry volume, filtrate volume, slurry weight, solid percentage, densities of slurry, filtrate and residue. There are four equation to be used to calculate slurry volume, slurry weight, solid percentage, and percent yield of alumina extraction that will be explained belows:

\section{A Slurry Volume Determination}

For knowing slurry volume resulting from digesting bauxite tailing with caustic soda using pressurized reactor, digested slurry product is pumped into Mixer (diameter $76.50 \mathrm{~cm}$, height $157 \mathrm{~cm}$, total volume $700 \mathrm{~L}$ ). From the callibration result, the relation between height of slurry level with its volume in Mixer is stright line with the equation is follows Vsl=4.176x +15.83 as shown in Figure II, where Vsl is slurry volume and $x$ is the height of slurry level in Mixer. The heighest slurry level in Mixer is $157 \mathrm{~cm}$ which correlates with slurry volume of $680 \mathrm{~L}$. On the other hand, the height slurry level of $0 \mathrm{~cm}$ shows slurry volume of $20 \mathrm{~L}$, it means that bottom part of Mixer has volume of $20 \mathrm{~L}$.

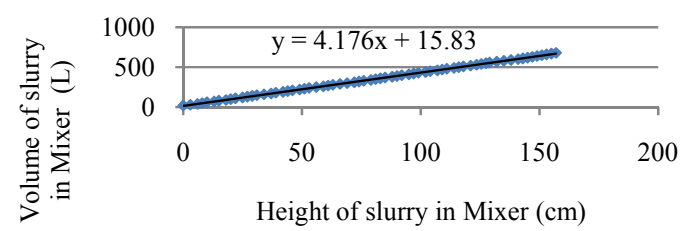

FIGURE II. RELATION BETWEEN HEIGHT OF SLURRY LEVEL VERSUS SLURRY VOLUME IN MIXER

\section{B Slurry Weight Determination}

Slurry weight in Mixer can be calculated by using the equation: $\mathrm{W}_{\mathrm{sl}}=(4.176 \mathrm{x}+15.83) * \rho_{\mathrm{sl}}$.

Data of the height of slurry level and slurry densities from nine experiment was collected, so by inputing those 
data into the above equation, the weight of slurry from nine digesting processes can be obtained as shown in Table I.

\section{Solid Weight Determination}

Solid weight can be obtained using the equation:

$$
\mathrm{W}_{\mathrm{s}}=\left(\rho_{\mathrm{sl}}-\rho_{\mathrm{l}}\right) /\left(\rho_{\mathrm{s}}-\rho_{\mathrm{l}}\right) \rho_{\mathrm{s}}(4.176 \mathrm{x}+15.83)
$$

The same as part B, by inputing the data of densities (slurry, filtrate, and red mud) and the height of slurry level, solid weight contained in the slurry can be obtained as shown in Table I.

\section{Solid Percentage Determination}

Solid percentage can be obtained by using the equation:

$$
\mathrm{S}=\left(\rho_{\mathrm{sl}}-\rho_{\mathrm{l}}\right) /\left(\rho_{\mathrm{s}}-\rho_{\mathrm{l}}\right)\left(\rho_{\mathrm{s}} / \rho_{\mathrm{sl}}\right) * 100(\%)
$$

The same as part B, by inputing the data of densities (slurry, filtrate, and red mud), solid percentage can be obtained as shown in Table I.

\section{E Percent Yield of Alumina Extraction Determination}

Percent yield of alumina extraction can be obtained using the equation: $\mathrm{E}=[10(4.176 \mathrm{x}+15.83)[1-(\rho \mathrm{s} l-\rho \mathrm{l}) /(\rho \mathrm{s}-$ $\rho \mathrm{l})]^{*}[\mathrm{cl} / \mathrm{FxF}](\%)$

The same as part B, by inputing the data of densities (slurry, filtrate, and red mud), the height of slurry level, weight and grade of feed, percent yield of alumina extraction can be obtained as shown in Table I.

Acurate result of percent yield of alumina extraction calculation is depended on homogeneous slurry in Mixer, sampling method, and accuracy on sample analysis both phisical and chemical properties.

\section{TABLE I RESULT OF THE EXPERIMENT}

\begin{tabular}{|c|c|c|c|c|c|}
\hline \multicolumn{6}{|l|}{$\begin{array}{l}\text { Slurry weight in } \\
\text { Mixer (kg) }\end{array}$} \\
\hline $\mathrm{Wsl}=(4.176 \mathrm{x}+15.83) \rho$ & 286,1 & 277,6 & 301,0 & 300,0 & 268,7 \\
\hline $\mathrm{sl}$ & 1 & 6 & 8 & 7 & 6 \\
\hline \multicolumn{6}{|l|}{$\begin{array}{l}\text { Filtrate volume in } \\
\text { Mixer (L) }\end{array}$} \\
\hline $\mathrm{V}_{1}=\mathrm{V}_{\mathrm{sl}}\left[1-\left(\rho_{\mathrm{sl}}-\rho_{\mathrm{l}}\right) /\right.$ & 174,6 & 161,5 & 192,3 & 182,1 & 150,1 \\
\hline$\left.\left(\rho_{\mathrm{s}}-\rho_{1}\right)\right]$ & 0 & 4 & 8 & 5 & 0 \\
\hline \multicolumn{6}{|l|}{$\begin{array}{l}\text { Red mud weight in } \\
\text { Mixer }(\mathrm{kg})\end{array}$} \\
\hline $\begin{array}{l}W s=\left(\rho_{\mathrm{sl}}-\rho_{\mathrm{l}}\right) /\left(\rho_{\mathrm{s}}-\right. \\
\left.\rho_{1}\right) \rho \mathrm{s}(4.176 \mathrm{x}+15.83)\end{array}$ & 71,35 & 80,58 & 70,22 & 86,95 & 85,64 \\
\hline \multicolumn{6}{|l|}{$\begin{array}{l}\text { Solid percentage in } \\
\text { Mixer (\%) }\end{array}$} \\
\hline $\begin{array}{l}\mathrm{S}=\left(\rho_{\mathrm{sl} 1}-\rho_{1}\right) /\left(\rho_{\mathrm{s}}-\rho_{\mathrm{l}}\right) \\
\left(\rho_{\mathrm{s}} / \rho_{\mathrm{sl}}\right) \times 100(\%)\end{array}$ & 24,94 & 29,02 & 23,32 & 28,98 & 31,87 \\
\hline \multicolumn{6}{|l|}{$\begin{array}{l}\mathrm{E}=\mathrm{Al}_{2} \mathrm{O}_{3} \text { extraction } \\
(\%)\end{array}$} \\
\hline $\begin{array}{l}\mathrm{E}=[10(4.176 \mathrm{x}+15.83) \\
{\left[1-\left(\rho_{\mathrm{sl}}-\rho_{\mathrm{l}}\right) /\left(\rho_{\mathrm{s}}-\right.\right.} \\
\left.\left.\rho_{\mathrm{l}}\right)\right]^{*}\left[\mathrm{c}_{\mathrm{l}} / \mathrm{Fx}_{\mathrm{F}}\right](\%)\end{array}$ & 46,63 & 39,63 & 30,45 & 23,06 & 15,84 \\
\hline
\end{tabular}

\begin{tabular}{|l|r|r|r|r|r|}
\hline $\begin{array}{l}\text { No. of the } \\
\text { experiment }\end{array}$ & $\mathbf{1}$ & $\mathbf{2}$ & $\mathbf{3}$ & $\mathbf{4}$ & $\mathbf{5}$ \\
\hline Reaction time (hour) & 1 & 1 & 1 & 1 & 1 \\
\hline Lime $(\mathrm{kg})$ & 3,0 & 4,5 & 6,0 & 7,5 & 9,0 \\
\hline $\begin{array}{l}\text { Height of slurry level } \\
(\mathrm{X})(\mathrm{cm})\end{array}$ & 44,8 & 43 & 48,95 & 48,09 & 40,29 \\
\hline $\begin{array}{l}\text { Constant value of } \\
\text { equation }(\mathrm{a})\end{array}$ & 4,176 & 4,176 & 4,176 & 4,176 & 4,176 \\
\hline $\begin{array}{l}\text { Constant value of } \\
\text { equation }(\mathrm{b})\end{array}$ & 15,83 & 15,83 & 15,83 & 15,83 & 15,83 \\
\hline $\begin{array}{l}\mathrm{Slurry} \text { volume }=\mathrm{V}_{\mathrm{sl}}= \\
4.176 \mathrm{x}+15.83\end{array}$ & 202,9 & 195,4 & 220,2 & 216,6 & 184,0 \\
\hline $\begin{array}{l}-\mathrm{Slurry} \text { density }\left(\rho_{\mathrm{sl}}\right) \\
(\mathrm{g} / \mathrm{mL})\end{array}$ & 1,41 & 1,421 & 1,367 & 1,385 & 1,46 \\
\hline $\begin{array}{l}-\mathrm{Filtrate} \text { density }\left(\rho_{1}\right) \\
(\mathrm{g} / \mathrm{mL})\end{array}$ & 1,23 & 1,22 & 1,2 & 1,17 & 1,22 \\
\hline $\begin{array}{l}\text { - Red mud density } \\
\left(\rho_{\mathrm{s}}\right)(\mathrm{g} / \mathrm{mL})\end{array}$ & 2,52 & 2,38 & 2,52 & 2,52 & 2,52 \\
\hline $\begin{array}{l}-\mathrm{Al} \mathrm{O}_{2} \text { content in } \\
\text { filtrate }\left(\mathrm{C}_{\mathrm{l}}\right)(\mathrm{g} / \mathrm{L})\end{array}$ & 64,55 & 59,29 & 38,25 & 30,6 & 25,5 \\
\hline $\begin{array}{l}-\mathrm{Al} \mathrm{O}_{2} \mathrm{O}_{3} \text { content in red } \\
\text { mud }\left(\mathrm{x}_{\mathrm{S}}\right)(\%)\end{array}$ & 19,13 & 23,11 & 19,76 & 19,76 & 22,63 \\
\hline $\begin{array}{l}-\mathrm{Al}{ }_{2} \mathrm{O}_{3} \text { content in } \\
\text { feed }\left(\mathrm{x}_{\mathrm{F}}\right)(\%)\end{array}$ & 27,89 & 27,89 & 27,89 & 27,89 & 27,89 \\
\hline $\begin{array}{l}\text { Dried weight of feed } \\
\left(\mathrm{W}_{\mathrm{F}}\right)(\mathrm{kg})\end{array}$ & 86,66 & 86,66 & 86,66 & 86,66 & 86,66 \\
\hline
\end{tabular}

Based on Tabel I, plotting between lime doses versus percent yield of $\mathrm{Al}_{2} \mathrm{O}_{3}$ extraction can be prepared as shown in Figure III. From Figure III, it can be seen that lime doses provide a significant effect on the extraction of $\mathrm{Al}_{2} \mathrm{O}_{3}$. Percent yield of $\mathrm{Al}_{2} \mathrm{O}_{3}$ extraction tend to decrease by the increase of lime doses. The value of percent yield of $\mathrm{Al}_{2} \mathrm{O}_{3}$ extraction is $50.75 \%$ by using $3 \mathrm{~kg}$ of lime, then decreases to $16.77 \%$ by using $9 \mathrm{~kg}$ of lime. The cause of this phenomena could be explained by some reactions that might occur in bauxite tailing digesting as follows: $\mathrm{Al}_{2} \mathrm{O}_{3}$ contained in bauxite tailing is dissolved with $\mathrm{NaOH}$ to form $\mathrm{Na}_{2} \mathrm{O} \cdot \mathrm{Al}_{2} \mathrm{O}_{3}: \mathrm{Al}_{2} \mathrm{O}_{3} \cdot 3 \mathrm{H}_{2} \mathrm{O}+2 \mathrm{NaOH}=\mathrm{Na}_{2} \mathrm{O} \cdot \mathrm{Al}_{2} \mathrm{O}_{3}+4$ $\mathrm{H}_{2} \mathrm{O}$

Because reactive silica is also contained in bauxite tailing, and lime was added as desilication agent for digesting process in this experiment, therefore it will be dissolved as well with $\mathrm{NaOH}$ and $\mathrm{Ca}(\mathrm{OH})_{2}$ as follows: $\mathrm{SiO}_{2}+2 \mathrm{NaOH}+$ $\mathrm{Ca}(\mathrm{OH})_{2}=\mathrm{Na}_{2} \mathrm{O} \cdot \mathrm{CaO} \cdot \mathrm{SiO}_{2}+2 \mathrm{H}_{2} \mathrm{O}$.

Then both products of chemical reaction (1) and (2) will react as follows: $\mathrm{Na}_{2} \mathrm{O} \cdot \mathrm{Al}_{2} \mathrm{O}_{3}+2\left(\mathrm{Na}_{2} \mathrm{O} \cdot \mathrm{CaO} \cdot \mathrm{SiO}_{2}\right)+2 \mathrm{H}_{2} \mathrm{O}=$ $\mathrm{Na}_{2} \mathrm{O} \cdot 2 \mathrm{CaO} \cdot \mathrm{Al}_{2} \mathrm{O}_{3} \cdot 2 \mathrm{SiO}_{2}+4 \mathrm{NaOH}$

$\mathrm{Na}_{2} \mathrm{O} \cdot 2 \mathrm{CaO} \cdot \mathrm{Al}_{2} \mathrm{O}_{3} \cdot 2 \mathrm{SiO}_{2}$ will precipitate together with red mud.

\section{TABLE II RESULT OF THE EXPERIMENT (CONTINUED)}

\begin{tabular}{|l|r|r|r|r|}
\hline No. of the experiment & $\mathbf{6}$ & $\mathbf{7}$ & $\mathbf{8}$ & $\mathbf{9}$ \\
\hline Reaction time (hour) & 1 & 1,5 & 2 & 2,5 \\
\hline Lime $(\mathrm{kg})$ & 3,0 & 3,0 & 3,0 & 3,0 \\
\hline $\begin{array}{l}\text { Height of slurry level } \\
(\mathrm{X})(\mathrm{cm})\end{array}$ & 44 & 42,5 & 34 & 50 \\
\hline $\begin{array}{l}\text { Constant value of equation } \\
(\mathrm{a})\end{array}$ & 4,176 & 4,176 & 4,176 & 4,176 \\
\hline $\begin{array}{l}\text { Constant value of equation } \\
(\mathrm{b})\end{array}$ & 15,83 & 15,83 & 15,83 & 15,83 \\
\hline $\begin{array}{l}\text { Slurry volume }=\mathrm{V}_{\mathrm{sl}}= \\
4.176 \mathrm{x}+15.83\end{array}$ & 199,574 & 193,31 & 157,814 & 224,63 \\
\hline - Slurry density $\left(\rho_{\mathrm{sl}}\right)(\mathrm{g} / \mathrm{mL})$ & 1,342 & 1,427 & 1,432 & 1,44 \\
\hline $\begin{array}{l}\text { - Filtrate density }\left(\rho_{\mathrm{l}}\right) \\
(\mathrm{g} / \mathrm{mL})\end{array}$ & 1,24 & 1,26 & 1,24 & 1,21 \\
\hline
\end{tabular}




\begin{tabular}{|c|c|c|c|c|}
\hline $\begin{array}{l}\text { - Red mud density }\left(\rho_{\mathrm{s}}\right) \\
(\mathrm{g} / \mathrm{mL})\end{array}$ & 2,52 & 2,77 & 2,69 & 2,69 \\
\hline $\begin{array}{l}-\mathrm{Al}_{2} \mathrm{O}_{3} \text { content in filtrate } \\
\left(\mathrm{C}_{1}\right)(\mathrm{g} / \mathrm{L})\end{array}$ & 65,70 & 85,1 & 89,9 & 53,6 \\
\hline $\begin{array}{l}-\mathrm{Al}_{2} \mathrm{O}_{3} \text { content in red mud } \\
\left(\mathrm{x}_{\mathrm{S}}\right)(\%)\end{array}$ & 29,48 & 21,52 & 20,72 & 21,7 \\
\hline $\begin{array}{l}-\mathrm{Al}_{2} \mathrm{O}_{3} \text { content in feed }\left(\mathrm{x}_{\mathrm{F}}\right) \\
(\%)\end{array}$ & 27,89 & 27,89 & 27,89 & 27,89 \\
\hline $\begin{array}{l}\text { Dried weight of feed }\left(\mathrm{W}_{\mathrm{F}}\right) \\
(\mathrm{kg})\end{array}$ & 86,66 & 86,66 & 86,66 & 86,66 \\
\hline \multicolumn{5}{|l|}{ Slurry weight in Mixer (kg) } \\
\hline $\mathrm{Wsl}=(4.176 \mathrm{x}+15.83) \rho \mathrm{sl}$ & 267,83 & 275,85 & 225,99 & 323,47 \\
\hline \multicolumn{5}{|l|}{ Filtrate volume in Mixer (L) } \\
\hline $\mathrm{V}_{1}=\mathrm{V}_{\mathrm{sl}}\left[1-\left(\rho_{\mathrm{sl}}-\rho_{\mathrm{l}}\right) /\left(\rho_{\mathrm{s}}-\rho_{\mathrm{l}}\right)\right]$ & 183,67 & 171,93 & 136,92 & 189,72 \\
\hline \multicolumn{5}{|l|}{$\begin{array}{l}\text { Red mud weight in Mixer } \\
(\mathrm{kg})\end{array}$} \\
\hline $\begin{array}{l}\text { Ws }=\left(\rho_{\mathrm{sl}}-\rho_{\mathrm{l}}\right) /\left(\rho_{\mathrm{s}}-\right. \\
\left.\rho_{1}\right) \rho \mathrm{s}(4.176 \mathrm{x}+15.83)\end{array}$ & 40,08 & 59,22 & 56,21 & 93,90 \\
\hline \multicolumn{5}{|l|}{$\begin{array}{l}\text { Solid percentage in Mixer } \\
(\%)\end{array}$} \\
\hline $\begin{array}{l}\mathrm{S}=\left(\rho_{\mathrm{sl}}-\rho_{1}\right) /\left(\rho_{\mathrm{s}}-\rho_{\mathrm{l}}\right)\left(\rho_{\mathrm{s}} / \rho_{\mathrm{sl}}\right) \\
\mathrm{x} 100(\%)\end{array}$ & 14,96 & 21,47 & 24,87 & 29,03 \\
\hline \multicolumn{5}{|l|}{$\mathrm{E}=\mathrm{Al}_{2} \mathrm{O}_{3}$ extraction $(\%)$} \\
\hline $\begin{array}{l}\mathrm{E}=[10(4.176 \mathrm{x}+15.83)[1- \\
\left.\left(\rho_{\mathrm{sl}}-\rho_{\mathrm{l}}\right) /\left(\rho_{\mathrm{s}}-\rho_{\mathrm{l}}\right)\right]^{*}\left[\mathrm{c}_{\mathrm{l}} / \mathrm{Fx}_{\mathrm{F}}\right] \\
(\%)\end{array}$ & 49,93 & 60,54 & 50,93 & 42,07 \\
\hline
\end{tabular}

So, based on both chemical reactions (2) and (3) above, the more lime added, the more sodium aluminate will react with lime to produce sodalite mixed with red mud. As a result, percent yield of $\mathrm{Al}_{2} \mathrm{O}_{3}$ extraction will decrease. This result is paralell with the statement of previous researcher stated that the higher reactive silica contained in bauxite, the higher sodalite produced will be; on the other hand, percent yield of $\mathrm{Al}_{2} \mathrm{O}_{3}$ extraction will decrese because of more sodium aluminate produced will react with sodium silicate to produce sodalite [14].

The effect of reaction time to the percent yield of $\mathrm{Al}_{2} \mathrm{O}_{3}$ extraction is shown in Figure IV. In this research, bauxite tailing (-150 mesh of particle size) was digested with $\mathrm{NaOH}$ at the temperature of $140^{\circ} \mathrm{C}$ and pressure 4 atmosphere using steam as heating media. From the Figure IV, it can be seen that percent yield of $\mathrm{Al}_{2} \mathrm{O}_{3}$ extraction tend to fluctuate in the range of $44.29-62.79 \%$ by varying reaction time between 1.0-2.5 hours in which 1.5 hours is the highest value. The decrease of $\mathrm{Al}_{2} \mathrm{O}_{3}$ extraction by the increase time reaction above 1.5 hours may be caused by sodium and/or calcium silicate occured during digesting process react with sodium aluminate solution to produce sodalite $\left(\mathrm{Na}_{2} \mathrm{O} \cdot 2 \mathrm{CaO} \cdot \mathrm{Al}_{2} \mathrm{O}_{3}\right.$. $\left.2 \mathrm{SiO}_{2}\right)$ as explained above. So, the longer reaction time, the higher the amount of sodium aluminate that react with sodium silcate will be. As a reslt, percent yield of $\mathrm{Al}_{2} \mathrm{O}_{3}$ extraction will decrease.

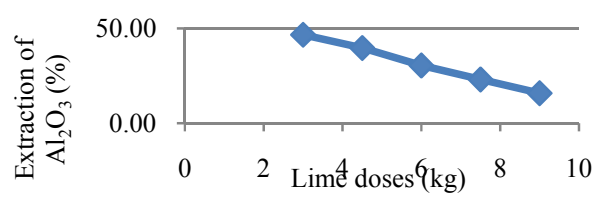

FIGURE III. RELATION BETWEEN LIME DOSES VERSUS PERCENT EXTRACTION OF AL2O3

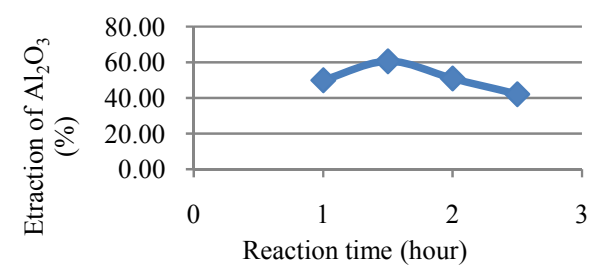

FIGURE IV. RELATION BETWEEN REACTION TIME VERSUS
PERCENT EXTRACTION OF AL2O3

\section{CONCLUSION}

Percent yied of alumina extraction from bauxite tailing digesting using caustic soda at the temperature of $140^{\circ} \mathrm{C}$ and pressure 4 atmosphere can be determined by using four equations without weighing of the slurry obtained from digestion process. Those four equation are 1) $\left.\left.\mathrm{V}_{\mathrm{sl}}=4.176 \mathrm{x}+15.83 ; 2\right) \mathrm{W}_{\mathrm{sl}}=(4.176 \mathrm{x}+15.83) * \rho_{\mathrm{sl}} ; 3\right) \mathrm{S}=\left(\rho_{\mathrm{sl}}-\right.$ $\left.\rho_{\mathrm{l}}\right) /\left(\rho_{\mathrm{s}}-\rho_{\mathrm{l}}\right)\left(\rho_{\mathrm{s}} / \rho_{\mathrm{sl}}\right) \times 100(\%)$, and 4$) \mathrm{E}=[10(4.176 \mathrm{x}+15.83)$ $\left[1-\left(\rho_{\mathrm{sl}}-\rho_{\mathrm{l}}\right) /\left(\rho_{\mathrm{s}}-\rho_{\mathrm{l}}\right)\right]^{*}\left[\mathrm{c}_{\mathrm{l}} / \mathrm{Fx}_{\mathrm{F}}\right](\%)$. Some data needed for determination of percent yield of alumina extraction are densities of slury, filtrate, and red mud as well as alumina contents of them. The first data that is obtained is slurry volume, followed by slurry weight, slurry solid percentage, and finally calculation of percent yield of alumina extraction. From this digesting process evaluation, it can be concluded that by the increase of lime added into the process, percent yield of alumina extraction obtained tend to decrease from $50.75 \%$ by using $3 \mathrm{~kg}$ of lime to $16.77 \%$ by using $9 \mathrm{~kg}$ of lime. Whereas, variation of reaction time between 1.0-2.5 hours, percent yield of alumina extraction tend to fluctuate in the range of $44.29-62.79 \%$ in which 1.5 hours of reaction time is the highest percent yield. By implementing four equation described above, weighing of the slurry in Mixer is not needed. Acurate result of this research is depended on homogeneous slurry samples and a good sampling.

\section{ACKNOWLEDGMENT}

Thank to Ministry of Energy and Mineral Resources of Indonesia for funding research activity until this paper can be prepared. Thank is also conveyed to Mr. Kusna Wijaya and Mr. Ade Setia Permana for supporting this research activities including praparation and analysis all samples resulting from the research.

\section{REFERENCES}

[1] X.L. Pan, H.Y. Yu, K.W. Dong, G.F. Tu, and S.W. Bi, "Predesilication and digestion of gibbsitic bauxite with lime in sodium aluminate liquor", International Journal of Minerals, Metallurgy, and Materials, Vol. 19, Issue 11,pp. 973-977, November 2012.

[2] M. Tariq, M.M. Iqbal, A. Aziz, M. Shafiq, M. Sajid, and B Mohammad, "Recovery of Alumina from Khushab Bauxite by Leaching with Sulphuric Acid and Removal of Iron Impurity by Ethanol", Department of Mining University of Engineering and Technology Lahore; Central Analytical Facility Division, PINSTECH, Islamabad Pakistan; Department of Construction Environment Engineering, Korea University of Science and Technology, 305-350, Daejeon, Korea; College of Chemistry, Beijing Normal University, China, 2014.

[3] S.J. Palmer, R.L. Frost, and T.M. Nguyen, "Hydrotalcites and their role in coordination of anions in Bayer liquors: Anion binding in 
layered double hydroxides", Coordination Chemistry Reviews, Elsevier, 2009, 253(1-2):pp. 250-267.

[4] D.Kopeliovich, "Bayer process", http://www.substech.com/dokuwiki/doku.php?id=bayer_process, downloaded February $14^{\text {th }}, 2016$.

[5] A. Kontopoulos, D. Panias, and I. Paspaliaris, "Precipitation Of Monohydrate Alumina In The Bayer Process",. National Technical University Of Athens Universite Libre De Bruxelles Hellenic Alumina Industry Contract JOE3-CT95-0003, 1997.

[6] R. Thompson, Industrial Inorganic Chemicals : Production and Uses, The Royal Society of Chemistry, Cambridge CB4 4WF, UK., 1995.

[7] S. Zhang, H. Du, H. Xu, S. Wang, Y. Zhang, "Improved Ying precipitation of gibbsite from sodium aluminate solution by adding methanol", Hydrometallurgy 98 (2009) 38-44, elsevier, 2009.

[8] C. Marsh, "CFD Modelling of Alumina Calciner Furnaces", Seventh International Conference on CFD in the Minerals and Process Industries CSIRO, Melbourne, Australia 9-11 December 2009.

[9] Wikipedia, "Sodium 2016, https://en.wikipedia.org/wiki/Sodium_aluminate\#Uses, the free encyclopedia, downloaded February $\overline{1}^{\text {th }}, 2016$.

[10] F. Oxana, "How to Calculate Percent Solids by Weight", 2016, http://www.ehow.com/how_7519269_calculate-percent-solidsweight.html, downloaded February $14^{\text {th }}, 2016$.

[11] Anonim, "Percent Solids to Specific Gravity Conversion of Slurry", https://www.911metallurgist.com/blog/percent-solids-to-specificgravity-conversion-of-slurry, downloaded, February $14^{\text {th }}, 2016$.

[12] Pahlavan, "Experiment 6-Extraction Determination of Distribution Coefficient, Extraction of Benzoic Acid", CHEM 2423, downloaded February $14^{\text {th }}, 2016$.

[13] Anonim, "Calculating Percent Recovery \& Percent Yield", (CHE 276) Organic Chemistry Laboratory, Appendix, Totah rev. 8/2011, 91, downloaded February $14^{\text {th }}, 2016$.

[14] H.L. Chen, M. Lewellyn, O. Chamberlain, H. Heitner, F. Kula, Q. Dai, C. Franz, "Sodalite Scale Control In Alumina Bayer Process", Corrosion, Nashville, Tennessee, March 14-15, 2007. 